\title{
A Number or a Measure? The Hurrian Gloss in AIT 46
}

\author{
by I. Márquez Rowe - Madrid
}

AlT 46 is a small tablet from Alalah level IV inscribed with an Akkadian loan transaction. A copy of it was published by D. J. Wiseman on Pl. XII of his edition (1953). In the catalogue proper, on p. 46, he also provides a description of the text. So far, however, no attempt has been made to discuss the document in full (as a matter of fact, no complete transliteration or translation of the text is known to me). A possible explanation for this is the presence of a Hurrian gloss in 1.10 that gives meaning to one of the legal stipulations of the transaction and which still defies translation.

In this paper I therefore wish to consider the text and, in particular, the Hurrian word na-ri-ia-te-ni-ma.

\section{Transliteration (collated) ${ }^{1}$}

\begin{tabular}{|c|c|c|c|}
\hline \multirow[t]{4}{*}{ Obv. } & (Seal of Abba-AN) & 10 & : na-ri-ia-te-ni-ma \\
\hline & $a-n a p a-n i{ }^{\mathrm{I}} n i q-m e-p a$ LUGAL_-ri & & KÙ.BABBAR sár-pu id-din-ma \\
\hline & 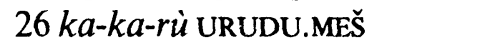 & & ù šum-ma iš-tu \\
\hline & $\begin{array}{l}\mathrm{NA}_{4}{ }^{\mathrm{uru}} a-l a-l a-a h^{\mathrm{ki}} \\
\mathrm{KI}{ }^{\mathrm{I}} d u-u d-d u\end{array}$ & & $\begin{array}{l}\text { ITI hil-ia-ri } i \text {-ti-iq } \\
\dot{u} u \text { u-șa-ab URUDU.MEŠ }\end{array}$ \\
\hline 5 & $\begin{array}{l}{ }^{1} k u-\dot{u}-t a \dot{u}^{\mathrm{I}} \mathrm{DINGIR-ma-al-ki} \\
i-n a \text { mI } \zeta u-m u-h a-a l-s e\end{array}$ & 15 & $\begin{array}{l}\text { IGI }{ }^{\text {I }} i r-k a b-d u \\
\text { IGI }{ }^{1} a-k i-{ }^{d}{ }^{\text {ISKKUR }}\end{array}$ \\
\hline Lo.E. & il-qè šum-ma & & IGI ${ }^{\mathrm{I}} a-k i-i a$ \\
\hline & $i-n a \operatorname{ITI} h i-i a-r i$ & & IGI I $k u-s ̌ a-i a$ \\
\hline Rev. & KÙ.BABBAR-pu ut-te-er-šu & U.E. & DUB.SAR \\
\hline
\end{tabular}

\section{Translation}

Before Niqmepa, the king, Kuta and Ilimalki received 26 talents of copper (according to) the weight stone of Alalah from Tuttu in the

1 I wish to thank C. B.F. Walker for his always kind permission to collate this and other tablets from Alalah kept in the British Museum. Mr. Oliver Dany (München) kindly corrected the English. 
month of Šmuhalše. (7) If they return the money in the month of Hiyaru, they will give $n$. of silver. (12) But if they let it go beyond the month of Hiyaru, then the copper will bear interest. 4 witnesses including scribe Kušaya.

Before we focus on the meaning of the Hurrian gloss in 1. 10, let us first briefly consider the language of the text. A look at the text reveals immediately that the scribe did not feel at home with Akkadian. As a matter of fact, in view of the gloss itself, there can be little doubt that the scribe, Kušaya, was a Hurrian native speaker. Therefore, one can surely assume that the non-standard forms of Akkadian used in AlT 46 must be the result of interference of his own tongue.

Since I have elsewhere discussed the Hurro-Akkadian language of Alalah in the middle of the second millennium B. C., I will here only list the following syntactical features. To begin with, one should mention the word order of the loan clause (11. $2-7) \mathrm{O}-\ldots \mathrm{S}-\ldots-\mathrm{V}$, where the object stands in the nominative case and the verb in singular does not agree with the plural subject of the Akkadian sentence (note that the two other verbs in 11. 9, 11 and 13, which refer to the same subject, are also in the singular; I have given preference to the contextual (and normative Akkadian?) translation. One may also assign to Hurrian influence the wrong case endings again of Kù.BABBAR-p $u$ in 1.9 and sár-pu in 1. 11, the wrong tense of the verb nadannu in 1.11, the use of the conjunction $u$ to introduce the apodosis in 1.14 and perhaps also the topicalised position of the verb in this very sentence.

\section{The Hurrian gloss}

When Wiseman gave a summary of the text, he did not venture on any discussion or translation of the word in 1.10; nevertheless he interpreted the clause in $11.10 \mathrm{f}$. in context: "the money (kaspu) is without interest(?), to be repaid in full in the month hiari". A few years later, in her dissertation on Hurrians and Hurrian at Alalah, A. Draffkorn Kilmer followed Wiseman's interpretation; unlike him, however, she identified the word as Hurrian nariyadeni and translated it accordingly as "principal (of money)" (1959: $187 \mathrm{f}$., including a full translation of $11.7-14$ ).

In $1984 \mathrm{G}$. Wilhelm published a note in which he revealed the Hurrian word for "five", namely nari(ya) (1984: $223 \mathrm{f}$.). At the end of his study, he included a suggestion made by $\mathrm{K}$. Deller according to which our gloss in AlT 46 would contain the Hurrian numeral and could tentatively be rendered as "fünffach". 


\section{A number?}

As a matter of fact, the first attempt to analyse the morphology of nari-ia-te-ni ${ }^{2}$ was made by E. Neu in a footnote of his article on the Hurrian essive in the light of the Hurro-Hittite bilingual (1988: 168 f. n. 30). Following Deller's suggestion to assume the root was the Hurrian word for "five", he compared it to the form tu-um-na-ti-ne attested in KBo. 32,13 ii 31 , equated to Hittite miiaues in i 30 , and deduced an afformative - $t i$-te used to build numeral abstracts (followed in turn by the Hurrian singular relator $=n e$ ). This interpretation he later reproduced in the edition of the bilingual text where he definitely established the suffix =ade/i (1996: 270) and noted a possible further example of this same construction, namely šu-ú-ga-at-te-ni (probably to be normalised šukk=ade: ne) attested in KUB 47,1 iii 9' (1996: 332 n. 61).

However, the example from the bilingual was interpreted differently by I. Wegner (1992: 230). Although Hittite miiaues is admittedly the numeral for "four" (in nom. pl. c.), she translated Hurrian tumn $(i)=$ ade=ne(=lla) as "jeweils vier", taking thus =ade as the suffix building distributives in Hurrian and used especially with numerals like sind $(e)=$ $a d(e)=a i\left(s i\right.$-in-ta-ta-a-i) in ChS I/1 16 Vs. ii $13^{\prime}$ or kig=ad(e)=ai in AlT 417: $2,3{ }^{3}$ These two latter examples had already been joined together by J. Friedrich in a short note on Hurrian numerals (1954/56: $368 \mathrm{f}$.). There he analysed the attestations in AlT 417, namely 2-ta-e (1. 1) and the abovementioned 3 ki-qa-ta-e (ll. 2 and 3 ) which paralleled the logographic writings 4-TA.ÀM (1. 4), 10-TA.ÀM (11. 5-7) and 30TA.ÀM (1. 8), and identified the Hurrian numerical distributive as =atae, thus corroborating E. A. Speiser's decipherment. Indeed, in his reviewarticle of Wiseman's edition Speiser (1954: 25) was the first one not only to assign the distributive meaning of Hurrian =dltae on the basis of AlT 417, but also to understand it as a composite suffix containing the element $=d / t=$ plus the adverbial morpheme $=a e^{4}$

But let us return to our gloss in AlT 46. How does all this discussion of Hurrian numeral formation affect our text? If we follow Neu's interpretation, the Hurrian word analysed as nariy $(a)=a d e=n e$ would represent the "numeral abstract" of five. Accordingly, the clause in $11.10 \mathrm{f}$.

2 For the analysis of $=m a$, see below.

3 And so possibly also the abovementioned example sukk=ade=ne.

${ }^{4}$ A further example of this construction is provided by another Hurrian gloss in a text from Alalah level IV. In AIT 114: 12 the word du-um-na-ta-la-an, marked with

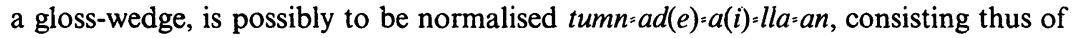
the numeral plus the distributive suffix and corresponding to the four-apiece distribution (written 4-TA.ÀM in 11.10 and 11) of footstools and chairs (see already Draffkorn Kilmer 1959: 209f.). 
would be rendered as: "they will give (a group of) five of silver". On the other hand, if we assume the numeral distributive meaning of the gloss, the sentence would run as follows: "they will give five apiece of silver".

In the first case, although one could understand "five (shekels)", the translation of the apodosis in question would not make much sense in the context of AlT 46. Besides, for such a statement in this sort of legal document one would rather expect an easier and in fact more common expression written with the figure 5 .

The second alternative may look more attractive because distributive numbers are indeed used in loan contracts to express the interest rate. ${ }^{5}$ Nevertheless, some problems with this are clearly apparent. To begin with, no mention is made of interest in this clause as opposed to the following lines $12-14$ which in fact stipulate the interest bearing clause (by means of the technical verb usssab). Secondly, as the resulting translation makes clear, the wording would be unusually obscure. Furthermore, one could once more object that such numerical expressions are, as a rule, rendered by more technical writing, especially by means of figures.

Finally, the suggested translation "fünffach" in Wilhelm's article does not agree either morphologically ${ }^{6}$ or, once again, contextually.

As a result of these contradictions one is inclined to doubt whether the Hurrian gloss in AlT 46: 10 contains hence the word for "five" nari $(y a)$ at all; so that an alternative reading seems to be justified.

\section{A measure?}

As I suggest, the Hurrian lexicon offers another, more likely, interpretation. The texts from Nuzi have preserved the Hurrian word nari, a weight measure attested so far for wool and cloth which was borrowed by the Hurro-Akkadian language of the Nuzi scribes and spelled accordingly nariu or narû (see CAD N/1, 368; cf. AHw. 747). In dealing with the wool weight system of Nuzi, Wilhelm (1988: 276283) proposed the equivalence 1 nariu $=1^{2 / 3}$ kutuktu $=1$ kutuktu +1 mana, i.e. 150 shekels, on the basis of HSS 13,288 (reproduced by M. A. Powell 1987/90: $514 \mathrm{f}$.). This was later challenged by C. Zaccagnini (1990: 315) who suggested in turn a ratio nariu: kutuktu of $1: 2$,

${ }^{5}$ See e.g. AlT 35:4f., 39:6 and 8, 40:4 f.; note, however, that these examples come from the level VII archive.

6 As regards the multiplicative numeral formation, it is worth noting that "tenfold" is rendered by eman=am $=\dot{g}=a$ in Mit. iv 32; note, on the other hand, that $1-\check{S} U$ in the

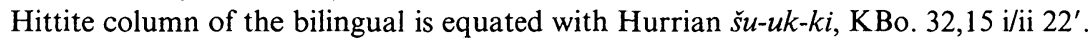


"more satisfying in terms of ratios and absolute figures", based on a possible scribal error in the aforementioned text from Nuzi.

As for the suffix in question, the Hurro-Hittite bilingual has shown that =ade is actually an afformative used to describe units of measure (as already noticed by Wilhelm 1988: 282 and so catalogued in 1992: 135). Indeed, KBo. 32,15 presents the following forms: $\check{s}$ i-ik-la-te (šigl= ade) Vs. i 6' and 7', ša-ha-at-na-ti (šaǵadn=ade) Vs. i 7', pa-ri-iz-za-te (pariss=ade) Vs. i $9^{\prime}$ and 11', and zu-wa-ta-at-te (suvad=ade) Vs. i 10'. In the light of these examples, our gloss could easily be understood morphologically as nari=ade. On the other hand, the connotation of the suffix to describe actual units is clearly deduced from their Hittite equivalents: 1 PA(-RI-SA $)$ for pariss=ade, 1/2 PA-RI-SI for suvad=ade, 1/2 Gín for šaǵadn=ade, and, in all likelihood, [1 GíN] for šigl=ade. Accordingly, nari=ade=ne in AlT 46:10 would mean, more or less literally, "a nari unit" or, in other words, "one nari". Regarding the analysis of the gloss, one last word must be said about the enclitic particle $=m a$. Although it is not impossible to interpret it as the Akkadian enclitic, its attachment to the gloss would rather point to its Hurrian origin. A connective $=m a$ is certainly attested in Hurrian texts. The problem, however, is to discover the meaning or force of such particles in general and this one in particular. In any case, what scholars working on Hurrian grammar soon realized was that some of these connectives were often used to introduce subordinate result clauses. In this regard I find it significant that the gloss in question introduces the apodosis of $11.10 \mathrm{f}$. Interestingly, the verb in this clause also carries the Akkadian enclitic - $m a$; and, furthermore, as stated above, the second apodosis in 1.14 is clearly introduced by the conjunction $u$, possibly influenced by Hurrian syntax.

Now, how does this interpretation agree with the meaning of the clause in $11.10 \mathrm{f}$. and the whole contents of AIT 46? If we first of all look at the sentence in $11.10 \mathrm{f}$., and, more particularly, at its structure: $n$. (= gloss) + KÙ.BABBAR șarpu + nadānu, there can be little doubt that the gloss in question must stand for a certain independent fixed amount, ${ }^{7}$ thus agreeing with our translation. What follows then is that

7 As opposed to the distributive or multiplicative numeral interpretation. Other attestations of 'amount' + Kù.BABBAR șarpu are AlT 49:2, 50:2, 67:5, 68:9, 70:10, 81:1, 394:1, 427:2; note also AlT 47:2 where the word Kù.BABBAR is omitted and șarpu stands alone after the logogram su "shekel" (with regard to this the writing su pul $p i$ in AlT 48:2, 18 and 393:2 may perhaps stand for an abbreviation or a mistake of the same expression). The reading of ZUR $=/ s ̦ a r /$ for șarpu in the Alalah texts was already put forward by G. Buccellati (1963: $223 \mathrm{f}$.). 
the amount of money represented by the Hurrian gloss should correspond to the principal of the loan, if $11.10 \mathrm{f}$. stipulate the interest-free clause (as understood by Wiseman and Draffkorn Kilmer), or to the principal plus the interest of the loan, if we understand 11. 12-14 as the additional interest-bearing clause. ${ }^{8}$ In the first case, this would imply that the sum of silver would be the equivalent value, or price, of the 26 talents of copper borrowed by Kuta and Ilimalki; and, in the second case, the addition of the value plus a round percentage of it. The question arises, therefore, whether the ratio copper:silver attested in the Alalah level IV texts confirms or disapproves our interpretation.

To deal with ratios, values or prices from a limited corpus of records like the present one always exposes oneself to the danger of reducing and even abstracting the numbers, disregarding the different essential variables and ending up with a completely distorted picture. Moreover, other premises must be taken into account. To begin with, the following ratio can only be subject to comparison if we assume that the nari-measures in Nuzi and in Alalah (level IV) are equal in value, that is 150 shekels according to Wilhelm's interpretation of HSS 13,288 or 160 shekels according to Zaccagnini's emendation. This assumption could, of course, be justified on account of a rough contemporaneity of the archives as well as the interrelated political and cultural background. Nevertheless, one must also bear in mind that contemporary and even related administrations used different metric systems. In this regard, AlT 46 states explicitly that the weight which was used to measure the copper on loan was the talent from Alalah, thus to be distinguished from other local weight systems.

The ratio copper : silver in Alalah was calculated by Wiseman at 450:1 in his introduction to the catalogue of the tablets (1953: 14, reproduced by Heltzer 1978: 88). No reference, however, is made to the sources for this calculation; nor did he indicate any distinction between the texts from one archive or another. In any case, what is very striking is that this value corresponds with the same ratio deduced by Cross for the Nuzi evidence (1937: 44). ${ }^{9}$ From the Alalah level IV material, the sale documents seem to provide the basic comparative data in order to help determine this value. According to these texts, the price of a person ranges from 25 (AlT 67 and 68) to 50 shekels of silver (AlT 66) and from 5 (AlT 71) to 51/2 talents of copper

8 Such ambiguous clauses are attested in loans from Nuzi (see e. g. Owen 1969: 37).

9 She there calculated a ratio of 1 shekel of silver for $450-900$ shekels of copper. See also Steele 1943: $33 \mathrm{ff}$. 
(AIT 69). ${ }^{10}$ As I have already emphasized above, the degree of probability for the relative value of copper based on such scarce and, therefore, arbitrary evidence is rather limited. ${ }^{11}$ Within this limited framework one can, however, still postulate an approximate relation of 1 talent of copper per 6.5 shekels of silver. ${ }^{12}$ On this basis, the equivalent in silver of the 26 talents of copper borrowed by Kuta and Ilimalki would be worth about 165 shekels of silver.

Despite the arbitrary nature of this calculation, the result seems to fit rather well with the calculated value of the nariu at Nuzi and would thus correspond to our translation of nari=ade $=n e=m a$ Kù.BABBAR șarpu. Accordingly, the clause in $11.10 \mathrm{f}$. would in turn describe the interestfree stipulation of the loan, and 11. 12-14 would then stipulate, literally, the dead-line when the 26 talents of copper would begin to accrue interest.

Of course, other objections, apart from the possible inaccuracy of the above calculation, can be raised by this translation. For example, the weight measure nariu is only attested at Nuzi with wool and cloth; on the other hand, it occurs in Alalah only in this text and side by side with the talent; also, why did the scribe use this Hurrian gloss instead of the more common shekels written in figures? Obviously it is not easy to answer these questions. Not only because we cannot grasp the details let alone all aspects of this and other transactions but because the personal scribal habits of Kušaya may also be involved. At any rate, I would not consider it surprising that a weight measure is used when dealing with silver; on the other hand, one should note

10 Similar prices for slaves in both copper and silver values are attested in Nuzi (see Cross 1937: 44).

$"$ Little indeed is known about the different possible variables involved in these purchases/sales. What the texts show and what one therefore should consider, for example, is the different category and type of the persons sold in the different documents: a male (PN) in AlT 68, a female (LÚ.SAL-tum) in AIT 66 and 67, a lad (șuhāru) in AlT 69 or a male slave (îR) in AlT 71. In addition, one should note that in AlT 70 another female (SAL-tum) is sold for 1000 shekels of silver. I have deliberately, and so again arbitrarily, excluded this example from my sample because of the extraordinarily high price, assuming a possible scribal error, thus following previous opinions (Speiser 1954: 24, Mendelsohn 1955: 68 n. 25, Klengel 1963: 12, Kienast 1976/80: 539 or Hoftijzer/van Soldt 1991: 203 n. 38).

12 This ratio seems to have been also in use at Nuzi and properly corresponds to Wiseman's calculation. Admittedly, both these results depended on the Babylonian weight standard of 1 talent $=3600$ shekels. However, on the basis of a new reading of AlT 401:4, Zaccagnini (1978: 67-69) deduced the 'North-Syrian' talent of 3000 shekels for Alalah level IV. 
that at Nuzi wool and cloth were also measured, though rarely, with the shekel-mina-talent-system and, furthermore, that this system may occur in the same text together with the nariu-system (see e. g. Zaccagnini 1990: 314).

\section{Conclusion}

As a conclusion to this note I would like to consider both the transaction and the parties involved in AlT 46.

Like AlT 46, several other documents found in the royal palace of Alalah level IV can be grouped in what we may call, not without a certain restraint, the "dossier of the Tuttu family". This family includes two generations, Tuttu and his son Ilimilimma, and covers the reigns of Niqmepa and his son and successor Ilimilimma. Given the relatively reduced corpus of legal texts unearthed from this palace archive, one may assume that they must have been active participants in the business life of the court of Alalah in the middle of the second millennium B. C. They appear in six (or perhaps nine) royal documents and their activity seems to have focused on monetary loans and the purchase of movable property. Tuttu's business, namely our loan of 26 talents of copper and the purchase of two oxen (AlT 74), are both presided by king Niqmepa. His son's more active affairs, which include several loans of silver ( 60 shekels in AIT 47, 24 shekels in AlT 48 and 30 shekels in AlT 49) and the purchase of a maid (AIT 70), ${ }^{13}$ are presided in turn by Niqmepa and Ilimilimma. In addition to this active participation, they are also attested as witnesses of other legal transactions officiated by the kings of Alalah (Tuttu in AlT 69:22 and 98e:Rs. 4, and Ilimilimma in AIT 87:24). This obviously strong tie with the king can be explained on account of their social category. Indeed, AIT 128 (collated), a list of maryannu's (1. 1 reads: țup-pi lú.mešma-ri-ia-ni-na giš GIGIR), mentions in $1.25{ }^{\mathrm{I}}$ DINGIR-lim-DINGIR-lim DUMU ${ }^{\mathrm{I}} t u$ - $t u$. That Tuttu must also have been a maryannu can be assumed on the basis of the hereditary character of such a category in Alalah at this time (cf. AlT 15, 91, as well as the same list AlT 128 where four sons of Irhari appear as maryannu's [11. 4, 8, 9, 29]).

It is significant that for such a picture one finds again striking similarities in the Nuzi evidence. Indeed, as summarized recently by M. P.

13 Despite the absence of filiation, it is possible to assume that the same Ilimilimma is being adopted in the well-known 'Nuzi manner' in AlT 16, purchases another maid in AlT 66 and is perhaps involved in the kallütu contract AlT 93. 


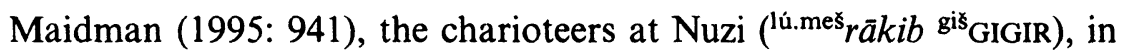
all likelihood to be equated with the maryannu's in Alalah, "appear the wealthiest and most active economically", engaging "in commerce for private gain and perhaps as government agents". But "of all the occupations associated with them, none appears with greater frequency than the office of judge. Perhaps a dozen charioteers are attested members of the judiciary while others served as deputies of the court." With regard to this, one should further note that the abovementioned list of maryannu's identifies many of the witnesses in the court of Alalah in the mid-second millennium B. C. ${ }^{14}$

What about the other party of the transaction in AlT 46? As a matter of fact, nothing is known about the borrowers Kuta and Ilimalki. D. Arnaud (1967: 164 n. 1), followed by N. F. Parise (1984: 132), considered them to be foreigners. This he argued on the basis of the qualification of the talent as $\mathrm{NA}_{4}{ }^{\text {uru }} a-l a-l a-a h^{\mathrm{ki}}$, also found in another loan contract from Alalah level IV, AlT 48:2,15 where the borrower with the clearly West Semitic name Baclaya is said to be a native of Canaan (1. 5). ${ }^{16}$ In addition, he remarked that the personal names of both borrowers are not attested elsewhere in the level IV corpus. This explanation is undoubtedly possible. Nevertheless, one should mention that a certain Ilimalik is attested in AIT 132:21 and an Ilimilki in AlT 191:14, both apparently residents of the kingdom of Alalah. On the other hand, it is stated nowhere in our text that Ilimalki and Kuta were not natives of Alalah, a specification which seems to have been rather adequate, if not necessary, in these documents.

As now regards the transaction proper, several basic questions arise: What is the purport of the loan?, What did Kuta and Ilimalki do with such a large amount of copper?, or, why is the loan transacted before and sealed by the king? Needless to say, the laconic wording of this genre of texts does not allow definite answers. Moreover, as a result of the little evidence for month names in this archive, ${ }^{17}$ it is not pos-

14 For example, Takuhuli, son of Uštaya (1. 7), witness in AIT 15:18, 47:18, 48:19, 72:15, 87:23; Akiya, son of Barta (1. 22), witness in AlT 15:19, 47:19; Takuhuli, son of Irhari (1. 4), witness in AlT 15:21; Šiptianta (1. 2), witness in AlT 16:23; or Šuwatiti (1. 12), witness in AlT 87:25.

15 The collation shows that the sign $\mathrm{KI}$ is certainly written on the tablet.

16 He referred also to AlT 33, a loan document from level VII dated to the reign of Irkabtum, where the silver on loan is weighed according to "the weight stone of Halab" (1. 2 and cf. 1. 14; for the text, see Zeeb 1991: 415 ff.) and the borrowers are said to come from the town of Airrašše (1. 4).

17 Note that the MN Sumuhalše is only attested here; for the Alalah level IV calendar see in general M. E. Cohen, 1993: 372-375. 
sible to determine the exact lapse of months before the interest would take effect. Despite these obvious difficulties, I would like to propose a tentative interpretation. Given the nature of loans and since copper was at that time and place a common means of payment, it seems quite clear that Kuta and Ilimalki required capital. Now, although one cannot discard that they borrowed the copper in order to fulfill obligations, like paying debts, or even to buy means of subsistence, the very large amount of copper seems to me to indicate that the nature of the loan is probably to be sought elsewhere.

In dealing with loan documents at Nuzi, Zaccagnini observed (1984: 147) that the use of copper in at least half of these loans was intended for overland trade transactions, "in which copper represents the capital entrusted to merchants, either for specific purchase or with a view to generical commercial profits." Furthermore, he suggested that this trade was mostly run by the royal administration and that the merchants acted thus on behalf of the palace (1977: 171-189, and 1984: 159).

In this light, AlT 46 may involve such a trade partnership agreement. The 26 talents of copper would be the capital. Kuta and Ilimalki would be the entrusted merchants, and could possibly belong to the palace administration (thus explaining the absence of identification like filiation or provenance). This would then account for the presence of Niqmepa, the king, as president and guarantor of the loan transaction. And the specific indication of the stone of Alalah as the weighing system employed for the copper could imply not that the borrowers were foreigners (as suggested by Arnaud or Parise) but, rather, that the trade operation was meant to be carried out abroad, where other systems were used. This possible interpretation of the business that lies behind the loan described in AIT 46 would confirm, in turn, to what extent members of the maryannu class were involved in and supported the royal enterprise of Alalah in the mid-second millennium B. C.

\section{Bibliographical References}

D. Arnaud 1967: Contribution à l'étude de la métrologie au IIe millénaire, RA 61, $151-169$.

G. Buccellati 1963: Due note ai testi accadici di Ugarit, OrAnt. 2, 223-228.

M. E. Cohen 1993: The Cultic Calendars of the Ancient Near East. - D. Cross 1937: Movable Property in the Nuzi Documents (= AOS 10).

A. Draffkorn Kilmer 1959: Hurrians and Hurrian at Alalah: An Ethno-Linguistic Analysis (Univ. of Pennsylvania PhD thesis). 
J. Friedrich 1954/56: Zu den churritischen Zahlwörtern, AfO 17, 368-369.

M. Heltzer 1978: Goods, Prices and the Organization of Trade in Ugarit. - J. Hoftijzer/W. H. van Soldt 1991: Texts from Ugarit Concerning Security and Related Akkadian and West Semitic Material, UF 23, 189-216.

B. Kienast 1976/80: Kauf. E. In Alalah und Ugarit, RlA 5, 530-541. - H. Klengel 1963: Zur Sklaverei in Alalah, Acta Antiqua Acad, Scient. Hung. 11, 1-15.

M. P. Maidman 1995: Nuzi: Portrait of an Ancient Mesopotamian Provincial Town, in: (ed.) J. M. Sasson, Civilizations of the Ancient Near East 931-947. - I. Mendelsohn 1955: On Slavery in Alalah, IEJ 5, 65-72.

E. Neu 1988: Zum hurritischen 'Essiv' in der hurritisch-hethitischen Bilingue aus Hattuša, Hethitica 9, 157-170; id. 1996: Das hurritische Epos der Freilassung I. Untersuchungen zu einem hurritisch-hethitischen Textensemble aus Hattuša (StBoT 32).

D. I. Owen 1969: The Loan Documents from Nuzu (Brandeis Univ. PhD Thesis).

N. F. Parise 1984: Unità ponderali e rapporti di cambio nella Siria del Nord, in: (ed. A. Archi) Circulation of Goods in Non-Palatial Context in the Ancient Near East 125-138. - M. A. Powell 1987/90: Maße und Gewichte, RIA 7, 457-517.

E. A. Speiser 1954: The Alalakh Tablets, JAOS 74, 18-25. - F. R. Steele 1943: Nuzi Real Estate Transactions (AOS 25).

I. Wegner 1992: Die selbständigen Personalpronomina des Hurritischen, SMEA 29, 227-237. - G. Wilhelm 1984: Hurritisch nari(ya), SMEA 24, 223-224; id. 1988: Zu den Wollmaßen in Nuzi, ZA 78, 276-283; id. 1992: Hurritische Lexikographie und Grammatik: Die hurritisch-hethitische Bilingue aus Boğazköy, Or. 61, 122-141. - D. J. Wiseman 1953: The Alalakh Tablets.

C. Zaccagnini 1977: The Merchant at Nuzi, Iraq 39, 171-189; id. 1978: A Note on the Talent at Alalah (AT 401), Iraq 40, 67-69; id. 1984: Transfer of Movable Property in Nuzi Private Transactions, in: (ed. A. Archi) [see Parise 1984] 139-159; id. 1990: The Nuzi Wool Measures Once Again, Or. 312-319. - F. Zeeb 1991: Studien zu den altbabylonischen Texten aus Alalah I: Schuldscheine, UF 23, 405-438. 